\section{Factors affecting the performance of Indonesian special food SMEs in entrepreneurial orientation in East Java}

\author{
Benny Hutahayan \\ Brawijaya University, Malang, Indonesia
}

Entrepreneurial orientation in East Java

Received 25 September 2018 Revised 12 March 2019 20 April 2019 19 June 2019

25 June 2019

Accepted 9 August 2019

\begin{abstract}
Purpose - This study aims to examine comprehensively the factors determining the performance of small and medium enterprises (SMEs) producing Indonesian special food in East Java.

Design/methodology/approach - This study is quantitative and qualitative. Primary data was collected from entrepreneurs in East Java, those producing Indonesian special food. Secondary data was obtained from the literature, literature study, journals, Central Bureau of Statistics and the office of industry, trade, cooperatives and SMEs in East Java. Areas selected for this study were Surabaya, Madiun, Malang, Pasuruan, Lamongan and Banyuwangi. The population was small and medium entrepreneurs producing Indonesian special food in the selected cities. Based on the PLS sampling rule, the number of samples in each research area was 50 , with total of 300 respondents $(50 \times 6)$. The methods of collecting primary data were interviews and questionnaire. Data analysis was done using GSCA.
\end{abstract}

Findings - The study firstly found the significant influence of entrepreneurial orientation on business strategies of SMEs producing Indonesian special food in East Java. SME managers have a high entrepreneurial orientation. Secondly, it found a significant influence of entrepreneurial orientation on business performance of SMEs producing Indonesian special food in East Java. Thirdly, the study found that government policy is not a moderating variable. Additionally, business strategies have a significant influence on the performance of SMEs producing Indonesian special food in East Java. Finally, dynamics of the environment and business strategy have a significant influence on the performance of manufacturing industry in South Sulawesi.

Originality/value - To know the effect of entrepreneurial orientation, environmental dynamism, consisting of uncertainty of environment and intensity of competition, and business strategies toward business performance. Considering the findings of the previous studies, the authors would like to re-examine the effect of entrepreneurial orientation on business performance, which also

(C) Benny Hutahayan. Published in Asia Pacific Journal of Innovation and Entrepreneurship. Published by Emerald Publishing Limited. This article is published under the Creative Commons Attribution (CC BY 4.0) licence. Anyone may reproduce, distribute, translate and create derivative works of this article (for both commercial and non-commercial purposes), subject to full attribution to the original publication and authors. The full terms of this licence may be seen at http://creativecommons.org/ licences/by/4.0/legalcode

Expression of concern: The Asia Pacific Journal of Innovation and Entrepreneurship is issuing an expression of concern for the following article: Hutahayan, B. (2019), "Factors affecting the performance of Indonesian special food SMEs in entrepreneurial orientation in East Java”, Asia Pacific Journal of Innovation and Entrepreneurship, Vol. 13 No. 2, pp. 231-246, to inform readers that concerns have been raised regarding the originality of the paper and that the peer review process was compromised. To date, the author has not responded to any requests for information, and an investigation is ongoing. Further information will be provided by APJIE as it becomes available.

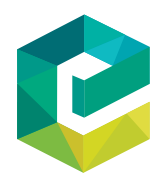

Asia Pacific Journal of Innovation and Entrepreneurship Vol. 13 No. 2, 2019 pp. $231-246$ pp. $231-246$
Emerald Publishing Limited Emerald Publishing Limited
2398-7812 DOI 10.1108/APJE-09-2018-0053 
APJIE 13,2

compares the findings of previous studies, especially, the one by Lee and Tsang (2003) on SMEs in Singapore.

Keywords Entrepreneurial orientation, Business strategies, Government policies, Performance of SMEs

Paper type Research paper

\section{Introduction}

Small and medium enterprises (SMEs) develop quite rapidly in Indonesia, especially those producing Indonesian special food. Traditional foods and beverages are typically consumed by certain groups of people with a special flavor distinctive of others. The traditional food contains a variety of basic foods, such as rice, sweet potatoes, sago and so forth; it also contains adequate nutrition, rich herbs and natural ingredients. The development of SMEs also requires the development of reliable human resources, as human resources will affect the productivity level and management quality. The external problems faced by small businesses in general are as follows. First, it is related with the unresolved issues handling the legality aspects of business entities and licensing procedures, the implementation of fair business competition and regional autonomy, particularly the willingness of the regions to implement the empowerment of small-scale enterprises. Second, the speedy recovery of macroeconomic conditions due to the increase in fuel price that is very influential in small-scale business operations. Third, it is the limited provision of financial institution services, especially investment credit. Fourth, it deals with the limited availability and quality of business development services for small businesses. Then, last but not least is the limited financial resources for micro-enterprises. There have been significant developments over the past five years for Indonesian food product business, as evidenced by the increasing number of business units that continue to grow each year significantly despite the slight increase; this indicates that a typical food business has a pretty good business opportunity.

SMEs are closely related to entrepreneurship. Various theories and studies in the field of entrepreneurship explain the importance of entrepreneurship orientation and its impact on business performance (Riyanti, 2003; Vitale et al., 2003; Nurhayati, 2004) by examining the impact of entrepreneurial orientation (consisting of elements innovative, proactive and risk), marketing orientation, culture and performance (consisting of sales growth, profit growth and asset growth). Lee and Tsang (2001) have investigated the impact of entrepreneurial orientation on venture growth as measured by the growth of sales and growth of profit. Their entrepreneurial orientation consists of the need for achievement, internal locus of control, selfreliance and extroversion. The results show positive in which internal locus of control, variable needs for achievement, self-reliance is not significant. Steward et al. (2003) show a negative effect of entrepreneurial orientation on goals. We need to know the effect of entrepreneurial orientation, environmental dynamism, consisting of the uncertainty of environment and intensity of competition, and business strategies toward business performance. Considering the findings of the previous studies, we would like to re-examine the effect of entrepreneurial orientation on business performance, which also compares the findings of previous studies, especially the one by Lee and Tsang (2003) on SMEs in Singapore.

This study also examines the influence of environmental dynamics and strategies as Hashim et al. (2001) have examined in Malaysian SMEs. Muryati (2004) shows that external factors have a significant positive effect on the intensity of competitive strategy, while the internal factors have a significant negative effect on the intensity of competitive strategy. 
Maupa (2004) reveals that external environmental factors do not significantly affect business strategies. From the results of the previous studies, this study aims to re-examine the effect of the environmental dynamics against business strategies and business performance. Nurhayati (2004) shows entrepreneurial skills are not significant to performance. Muryati (2004) confirms that internal factors, consisting of production, marketing, finance, human resources and corporate information systems, negatively affect competitive strategy.

The factorization of pull is the possibility of obtaining higher (financial) benefits, the desire to obtain higher responsibility and control over the decision-making process and the desire to improve individual abilities. Meanwhile, push factors to put more emphasis on employee motivation to leave their place of work and start a new business or something that is "pressing" someone to start entrepreneurship. The thing that must be considered is how to anticipate weaknesses and constraints faced by SME business people. The thing that should be noted is the entrepreneurial orientation in facing the dynamics of the environment to choose and implement management and strategies in an integrated manner so that improved performance and competitive advantage of SMEs can be achieved. Some characteristics of entrepreneurs as mentioned by Idrus (1999) include: self-confidence (selfconfidence), task-oriented (task result-oriented), dare to take risks (risk-taker in the form of time, money and health and soul), have leadership attitude (leadership), original, futureoriented, greatly influences the success or performance of the business being carried out. The entrepreneurial orientation of an entrepreneur can lead to increase in business performance. Based on the previous studies, especially on SMEs producing Indonesian special food in East Java, we know that SMEs in Batu show superior performance. Therefore, it is necessary to examine comprehensively the factors determining the performance of SMEs producing Indonesian special food in East Java.

\section{Literature review and hypotheses}

\section{The relationship of entrepreneurial orientation and business strategies}

A strategy can be defined as directives based on organizational scale and decisions on products, market scale and improvement on competitive elements (McCarthy, 2003). Neshamba (2003) suggest that successful business owners have a greater emphasis on market orientation where they sell goods or services. Olson (2000) confirms that there is no proven significant positive relationship between risk tolerance, locus of control and ambition with the decision to enter the market.

In fact, it is undeniable that the survival of a company depends on the ability of entrepreneurs to survive and excel in the competition. Thus, a strategy to achieve competitive advantage is indispensable. Porter (1980) argues that companies must create special competitiveness to have strong bargaining power in competition. With regard to determining, which business strategies can be superior in competition, it is necessary to know the concept of the marketing strategy known as 4P (Price, Product, Place and Promotion).

Research and development in entrepreneurship is the main strategy because it is related to creativity and innovation. It includes product research and development, price research and development, and promotion research and development. A business develops successfully because it has adequate research and development capability so as to create valuable and superior goods in the market.

H1. The better the entrepreneurial orientation, the more precise the business strategy applied to the small and medium business.

Entrepreneurial orientation in East Java $-$

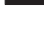


APJIE

13,2

The relationship of entrepreneurial orientation and business performance

Glancey et al. (1998) affirm that one's motivation in entrepreneurship is the "pull and push" factor. The "pull" factor is the possibility of obtaining a higher (financial) profit, a desire for greater responsibility and control over the decision-making process and the desire to improve the ability of the individual. Meanwhile, the "push" factor is more on self-motivation of employees to leave the place of work and start a new business; in other words, the "push" factor refers to things that are forcing a person to start becoming an entrepreneur.

Entrepreneurs, who have more push motivation, intend to sell or even close their business. Thus, the success of the business depends on the level of motivation of entrepreneurs. In other words, entrepreneurial orientation determines business performance. Some innovations to motivate individuals are focused on entrepreneurship, help to reach their full potential, give awards, encouraging to see from a broad perspective and educate about entrepreneurship (Tseng and Tseng, 2019).

Entrepreneurial orientation can lead to an increase in business performance (Brown, 1996; Covin and Slevin, 1991). Thus, according to Lumpkin and Dess (1996), market leaders often use innovation and breakthroughs in doing business.

H2. The better entrepreneurial orientation, the higher performance of SMEs producing Indonesian special food in East Java.

\section{The relationship of entrepreneurial orientation and business performance moderated by government policies}

Thurik and Wennekers (2004) in their research conclude that government policies control the economy by involving technology participation and consumer stability will drive business performance. Some empirical studies confirm the role of government policies on SMEs. Rasiah (2002) reveals a proactive autonomous, the government supports the development of SMEs in the form of public training and market information. According to Makhdoom et al. (2019) entrepreneurial orientation and collective entrepreneurship have a direct positive impact on innovation in SMEs.

Albaladejo and Romijn (2000) reveal that a company's innovation capability comes from two sources, internal and external sources. Internal sources consist of professional background of founders or managers, employment skills and technology efforts. The external source deal with the frequency of interaction with customers, suppliers, government agencies and industry associations. It has been found that geographical proximity to external parties and support from institutions especially from the government through the provision of financial assistance or knowledge transfer has a positive impact on innovation ability.

The government holds such an important role in promoting small business success, as through its policies, the government can encourage business performance improvement for small businesses. Government policies can include improving the quality of small business human resources through training, strengthening capital by facilitating access to capital, encouraging partnerships and providing protection for small businesses.

H3. The better the entrepreneurial orientation coupled with effective government policies, the higher performance of SMEs producing Indonesian special food in East Java.

The relationship of business strategies and business performance

Contingency theory states that the success of the company depends on how the company can relate to situational factors such as environment (Hashim et al., 2001). Their study 
shows that the three generic strategies of Porter are not only relevant to large companies but also SMEs. It is also been confirmed the relationship of business strategies and performance of SMEs moderated by the environment.

According to Covin and Slovin (1989), small enterprises with high-style strategy indexes or entrepreneurial firms, generally perform better in tight competition, whereas small enterprises with low-conscious strategy or conservative firms, generally perform well in a soft competition environment. The generic strategy of Covin and Slovin (1989) has a weak influence on performance (Pelham, 1999). Menguec et al. (2007) also saw that MO is positively associated with marketing differentiation and innovation strategies, but not in low-cost strategies. Rust et al. (2002) state the emphasis of costs relates to standardization and operational efficiency. Marketing performance is a factor that is often used to measure the strategy implemented by the company. A company strategy is always directed to produce good marketing performance and good financial performance.

Companies that are able to create a competitive advantage will have the power to compete with other companies because their products will remain in the interest of customers. Thus, design superiority has a positive effect on improving marketing performance. Some of the indicators used in assessing business performance are the profitability, productivity and market (Camision, in Sanchez and Marin, 2005).

H4. The more appropriate the business strategy, the higher the performance of SMEs producing Indonesian special food in East Java.

The relationship of environmental dynamics, business strategies, and business performance Environmental dynamics (environmental uncertainty and competitive level) and competitive strategies (differentiation strategy, low cost, focus and delivery performance) are closely related to performance (sales growth, profit, assets and market share). According to Hashim et al. (2001), the effectiveness of a strategy can be seen by understanding and knowing the corporate environment, so a business strategy must be in line with the organization's environment if it aims at the good organizational performance. In their research, the environment is measured through two dimensions, namely, the environmental uncertainty and competitive level, and business strategy are measured by three general strategies by Porter (1993). The dynamic environment has a more organic organizational structure in small companies. According to Marhaeni et al. (2019) human resources mediate part of the influence of social capital on empowerment; and transaction costs do not act as variables, mediating the effect of social capital on the empowerment of the small wooden handicraft industry in Bangli Regency. It is necessary for companies to adapt to the environment. The existence of information development requires companies to be responsive to the market. Anand and Ward (2004) have found that the dynamics of the environment and mobility have a positive and significant impact on market share and sales growth. Pelham (1999) in Suci (2009) states there is a relatively weak direct and indirect influence of the competitive environment on performance.

H5. The more appropriate the business strategy implemented with the environment dynamics, the higher the performance of SMEs producing Indonesian special food in East Java.

\section{Methodology}

This study is quantitative and qualitative. Primary data were collected from entrepreneurs in East Java, those producing Indonesian special food. Secondary data were obtained from
Entrepreneurial orientation in East Java

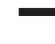


APJIE 13,2 the literature, literature study, journals, Central Bureau of Statistics, and the Office of Industry, Trade, Cooperatives, and SMEs in East Java. Areas selected for this study were for Surabaya, Madiun, Malang, Pasuruan, Lamongan and Banyuwangi. The population was small and medium entrepreneurs producing Indonesian special food in the selected cities. Based on the PLS sampling rule, the number of samples in each research area was 50, with total of 300 respondents $(50 \times 6)$. The method of collecting primary data were interviews and questionnaire. Data analysis were done using GSCA.

The following describes the operational definitions of each variable in this study. Entrepreneurial orientation is the behavior of the entrepreneur in managing the business. To measure its quality, we used an indicator listed in entrepreneurship characteristics. Meredith (1996) (in Suryana, 2006) brings out entrepreneurial traits as follows: confidence and optimism, work-oriented and result-oriented, risk-taking, leadership, originality and future-oriented. Environmental dynamics are seen as a change of environment both from within and outside the company that can bring new opportunities and threats for the company. Environmental dynamics in this study are viewed from two perspectives; the first is uncertainty, while the second is intensity. To measure this variable in the perspective of uncertainty, indicators developed from the concept of the major forces affecting industrial competition developed by Porter (1993) are used. Business strategies refer to the ability of the entrepreneur or company related to the analysis of the external and internal environment of the company, the formulation of the strategy, the implementation of plans designed to achieve goals, and the evaluation to get feedback in formulating the future strategy, with indicators of differentiation strategy, cost strategy and focus strategy. Government policies refer to the policies in the developing industry, especially small and medium industries. These are measured using three indicators, namely, training frequency, easy access to capital, and partnerships, taken from three previous researchers (Antonio et al., 2003; Dimitris and Dimitris, 2004; Stuart, 2009). Business performance refers to the level of achievement of a company within a certain period. The variable is based on the adaptation of Camison in Sanchez and Marin (2005) using three indicators to measure business performance, namely, profitability, productivity and market.

\section{Results}

\section{Validity testing}

Validity testing can be done by correlating each item score with the total score for each variable using correlation (r) product moment. Item or indicator is said to be valid if the value is $r>0.30$. The reliability testing technique is to use the Cronbach's alpha reliability coefficient value. Validity and reliability testing carried out through the SPSS program is based on the results of trial data on 50 respondents taken from outside the disktrik Dili, Baucau and Maliana. The correlation coefficient of each statement item is the total score of the overall question item. The following are the results of the validity test in Table I and reliability tests in Table II.

Table I shows that all indicator produces $r$ values above 0.30 , and thus, it can be said that the research instruments are valid.

\section{Reliability testing}

The following are the results of reliability testing using the Cronbach's alpha reliability coefficient value. The criteria decision is that if the value of the alpha reliability coefficient is greater than 0.6 then the variable is reliable. 


\begin{tabular}{|c|c|c|c|}
\hline Item & $r$-value & Result & $\begin{array}{l}\text { ntrepreneurlal } \\
\text { orientation in }\end{array}$ \\
\hline \multicolumn{3}{|l|}{ Entrepreneurship orientation (X1) } & \multirow[t]{7}{*}{ East Java } \\
\hline Confidence & 0.723 & Valid & \\
\hline Dependence on other people & 0.547 & Valid & \\
\hline Optimism & 0.49 & Valid & \\
\hline Need or thirst for achievement & 0.629 & Valid & \\
\hline Profit-oriented or results & 0.303 & Valid & \\
\hline \multirow{2}{*}{$\begin{array}{l}\text { Diligent and steadfast } \\
\text { Determination of hard work, motivation }\end{array}$} & 0.52 & \multirow{2}{*}{$\begin{array}{l}\text { Valid } \\
\text { Valid }\end{array}$} & \\
\hline & 0.652 & & \\
\hline Energetic & 0.411 & Valid & \\
\hline Full of initiative & 0.51 & Valid & \\
\hline Able to take risks & 0.366 & Valid & \\
\hline Love the challenge & 0.506 & Valid & \\
\hline Being able to lead can get along with other people & 0.537 & Valid & \\
\hline Respond to suggestions and criticism & 0.538 & Valid & \\
\hline Innovative & 0.511 & Valid & \\
\hline Creative & 0.386 & Valid & \\
\hline Flexible & 0.342 & Valid & \\
\hline Foresight & 0.303 & Valid & \\
\hline Perspective & 0.655 & Valid & \\
\hline \multicolumn{3}{|l|}{ Environmental dynamics (X2) } & \\
\hline Entrance barriers & 0.508 & Valid & \\
\hline Threat of substitute products & 0.639 & Valid & \\
\hline Competitive conditions & 0.516 & Valid & \\
\hline Supplier strength & 0.583 & Valid & \\
\hline Buyer strength & 0.618 & Valid & \\
\hline Product delivery & 0.737 & Valid & \\
\hline Promotion competition & 0.729 & Valid & \\
\hline Price competition & 0.761 & Valid & \\
\hline Competition of distribution channels & 0.47 & Valid & \\
\hline Raw material competition & 0.59 & Valid & \\
\hline \multicolumn{3}{|l|}{ Government policy (X3) } & \\
\hline UKM Management training & 0.849 & Valid & \\
\hline Ease of obtaining capital & 0.807 & Valid & \\
\hline Ease in increasing cooperation & 0.747 & Valid & \\
\hline \multicolumn{3}{|l|}{ Business strategy (Y1) } & \\
\hline Raw material prices & 0.618 & Valid & \\
\hline Production process costs & 0.56 & Valid & \\
\hline Product distribution costs & 0.551 & Valid & \\
\hline Price of product & 0.657 & Valid & \\
\hline Quality products & 0.777 & Valid & \\
\hline More useful products & 0.563 & Valid & \\
\hline Special services & 0.602 & Valid & \\
\hline Products vary & 0.609 & Valid & \\
\hline Certain service segments & 0.561 & Valid & \\
\hline Market selection & 0.528 & Valid & \\
\hline Product conformity & 0.534 & Valid & Table I. \\
\hline \multirow[t]{2}{*}{ Matching selling prices } & 0.616 & Valid & Test results for \\
\hline & \multicolumn{2}{|r|}{ (continued) } & validity \\
\hline
\end{tabular}


Item

$r$-value

Result

Business performance (Y2)

Advantage

Business assets

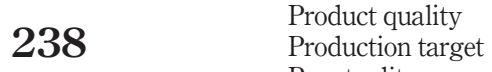

Punctuality

New product

Employee productivity

Sales volume

market position

Market growth
0.587

0.603

0.646

0.579

0.605

0.475

0.725

0.435

0.730

0.676
Valid

Valid

Valid

Valid

Valid

Valid

Valid

Valid

Valid

Valid

Table II shows that all variable produce alpha values above 0.60 , and thus, it can be said that the research instruments are reliable. Thus, the research instrument is worthy of being used as a variable measurement tool.

\section{Goodness of fit}

Goodness of fit model in GSCA is presented as follows. The result of the analysis shows that model is good, as the GFI value $>0.90$. From the FIT value of 0.499 , we can see that the total variant of all variables used in this study and the model can explain all existing variable up to0.499. The diversity of entrepreneurial orientation, business strategies, environmental dynamics, government policies and SME business performance that can be explained by the model is 49.9 per cent and the rest is explained by other variables not tested in the present study. The results of hypothesis testing on GSCA using $t$-test are presented in the following table.

Based on the results in Table I, the relationship among variables is now known. The first hypothesis is that the better entrepreneurial orientation, then the more appropriate business strategy applied to the SMEs. The GSCA results show a path coefficient of 0.298 and $p$-value of 0.000 (significant), so the hypothesis is accepted. The second hypothesis is that the better entrepreneurial orientation), the higher performance of SMEs producing Indonesian special food in East Java. The GSCA results show a path coefficient of 0.261 and $p$-value of 0.0246 (significant), so the hypothesis is accepted. The third hypothesizes that the better entrepreneurial orientation coupled with effective government policies, the higher performance of SMEs producing Indonesian special food in East Java. The results of GSCA show a path coefficient of the effect of policies on performance of -0.080 and $p$-value of 0.849 (not significant) and interaction effect of X1*X3 on performance of 0.126 and $p$-value of 0.772 (not significant), so the hypothesis is rejected. This shows that policies do not act as moderation. The fourth hypothesis is that the more appropriate in applying the business

Table II.

Variable reliability test

\begin{tabular}{|c|c|c|}
\hline Variable & Coefficient Cronbach's alpha & Decision \\
\hline Entrepreneurship orientation (X1) & 0,774 & Reliable \\
\hline Environmental dynamics (X2) & 0,733 & Reliable \\
\hline Government policy (X3) & 0,731 & Reliable \\
\hline Business strategy (Y1) & 0,753 & Reliable \\
\hline Business performance (Y2) & 0,806 & Reliable \\
\hline
\end{tabular}


strategy, the higher performance of SMEs producing Indonesian special food in East Java. The results of GSCA show a path coefficient of 0.169 and $p$-value of 0.0271 (significant), so the hypothesis is accepted. The fifth hypothesizes the more appropriate business strategy implemented with the environment dynamics, the higher performance of SMEs producing Indonesian special food in East Java. The results of GSCA show a path coefficient of the effect of business strategies on performance of -0.215 and $p$-value of 0.016 (significant), and interaction effect of $Y 1 * X 2$ on performance of 0.217 and $p$-value of $p$-value $=0.036$ (significant), so the hypothesis is accepted. This shows that environmental dynamics act as a quasi-moderation variable.

\section{Discussion}

The effect of entrepreneurial orientation on business strategies

The results of hypothesis testing in Table III show a significant influence of entrepreneurial orientation on business strategies of SMEs producing Indonesian special food in East Java. SME managers have a high entrepreneurial orientation, especially in terms of confidence and optimism. This means that in running the business, they always believe in the ability they have, they do not depend much on others, and their sense of optimism is good.

The high entrepreneurial orientation gives a positive and significant influence on the ability to determine the right business strategy, especially the differentiation strategy. This means that SME managers have the ability to set appropriate strategies for producing quality products, producing products offering better benefits than similar ones, formulating a variety of products, and providing the best service to their customers.

The results of this study extend the research conducted by Mahmud and Anomsari (2011), which shows that entrepreneurial orientation has a positive and significant impact on the business strategy set by owners and managers of SMEs on Jalan Barito Semarang. According to Porter (1980) argues that change must create competitiveness especially to

\begin{tabular}{|c|c|c|c|c|c|c|}
\hline Hypothesis & \multicolumn{2}{|c|}{ Relationship between variables } & Path coeff & $\mathrm{CR}$ & $p$ & Note \\
\hline 1 & $\begin{array}{l}\mathrm{X} 1=\text { entrepreneurial } \\
\text { orientation }\end{array}$ & $\begin{array}{l}\text { Y1= business } \\
\text { strategies }\end{array}$ & 0.298 & $9.67^{*}$ & 0.0000 & Accepted \\
\hline 2 & $\begin{array}{l}\mathrm{X} 1=\text { entrepreneurial } \\
\text { orientation }\end{array}$ & $\begin{array}{l}\text { Y2 = business } \\
\text { performance }\end{array}$ & 0.261 & $2.27^{*}$ & 0.0246 & Accepted \\
\hline \multicolumn{7}{|c|}{ Test on X3 as a Mediating Variable of X1 to Y2 } \\
\hline 3 & $\begin{array}{l}\mathrm{X} 3=\text { government } \\
\text { policies } \\
\mathrm{X} 1 * \mathrm{X} 3=\mathrm{X} 1 \\
\text { interaction with X3 }\end{array}$ & $\begin{array}{l}\mathrm{Y} 2=\text { business } \\
\text { performance } \\
\mathrm{Y} 2=\text { business } \\
\text { performance }\end{array}$ & $\begin{array}{l}-0.080 \\
0.126\end{array}$ & $0.19 \mathrm{ts}$ & $\begin{array}{l}0.8496 \\
0.7722\end{array}$ & Not a moderation \\
\hline \multicolumn{7}{|c|}{ Test on $X 2$ as a mediating variable of Y1to $Y 2$} \\
\hline 4 & $\begin{array}{l}\mathrm{X} 2=\text { environmental } \\
\text { dynamics } \\
\mathrm{Y} 1 * \mathrm{X} 2=\mathrm{Y} 1 \\
\text { interaction with } \mathrm{X} 2\end{array}$ & $\begin{array}{l}\text { Y2 = business } \\
\text { performance } \\
\text { Y2 = business } \\
\text { performance }\end{array}$ & $\begin{array}{l}-0.215 \\
0.217\end{array}$ & $\begin{array}{l}2.42^{*} \\
2.11^{*}\end{array}$ & $\begin{array}{l}0.0167 \\
0.0365\end{array}$ & $\begin{array}{l}\text { Quasi } \\
\text { moderation }\end{array}$ \\
\hline 5 & $\begin{array}{l}\text { Y1 = business } \\
\text { strategies }\end{array}$ & $\begin{array}{l}\text { Y2 = business } \\
\text { performance }\end{array}$ & 0.169 & $2.23^{*}$ & 0.0272 & Accepted \\
\hline
\end{tabular}

Notes: Decision: ts $=$ not signifiant; $*=$ significant at $\alpha 5 \%$

\section{Entrepreneurial orientation in East Java}


APJIE 13,2

Figure 1.

Research conceptual framework have a strong bargaining position in competition; that needs a strategy, so the company can excel than its competitors. The well-known marketing strategy concept is $4 \mathrm{P}$ (Product, Price, Place and Promotion). Furthermore, Suci (2009) adds that entrepreneurship research and development can be the main strategy because it is related to creativity and innovation, as a part of entrepreneurial orientation.

The study by Lee and Tsang (2001) observes the influence of entrepreneurial personality traits and network activities on business growth of about 168 Chinese entrepreneurs in small as well medium businesses in Singapore. The results indicate that:

- Experience, network activities, number of partners, locus of control and need for achievement has a positive effect on business growth.

- Two other personality traits, namely, self-reliance and extroversion, have negative effect on the number of partners.

- Education on business growth, moderated by firm size, positively affects large companies and negatively affects small companies.

- The entrepreneurial industry and managerial experience are the dominant factors affecting business growth.

The difference of our finding with the ones by Lee and Tsang (2001) are in the operational description of the entrepreneur personality into two variables, namely, the entrepreneurial orientation and the business strategy. Another difference lies in the use of measures of business growth, in which Lee and Tsang use business growth and development, while our study uses business performance. This means that entrepreneurial orientation influences business strategies especially in analyzing environment and formulating strategies.

\section{The effect of entrepreneurial orientation on business performance}

The results of hypothesis testing in Table I show a significant influence of entrepreneurial orientation on business performance of SMEs producing Indonesian special food in East Java. The

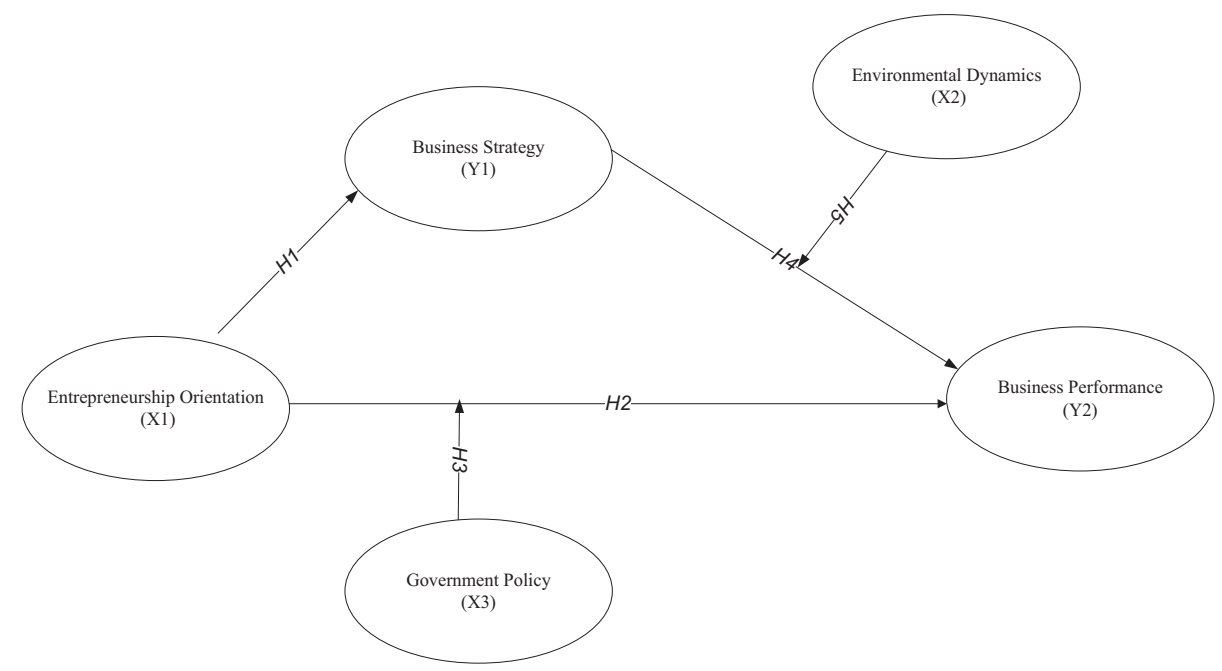




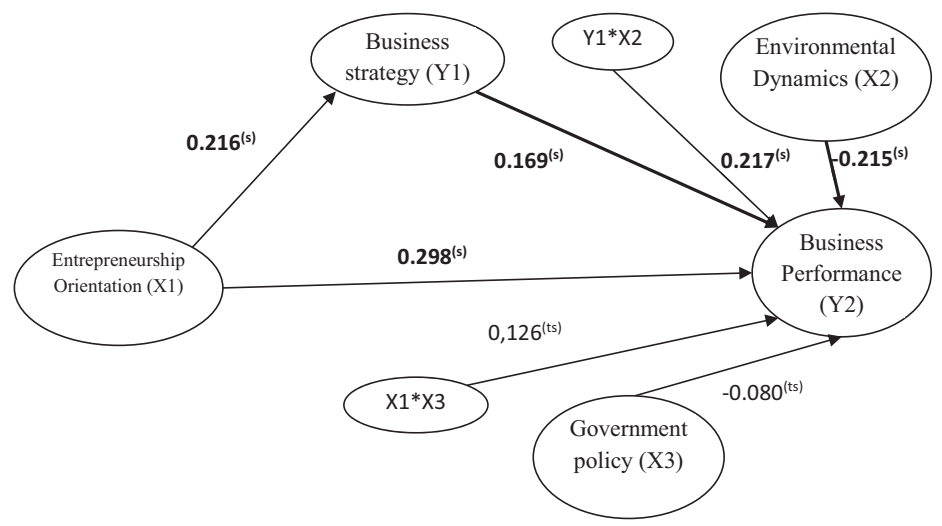

Entrepreneurial orientation in East Java

Figure 2.

Path diagram of hypothesis testing results

results of this study are in line with research conducted by Moeljadi (1999), which shows that the internal factors of the company, especially the high entrepreneurial orientation, will certainly affect business performance. Suci (2009) shows entrepreneurship orientation has a positive and significant impact on business performance in small and medium embroidery industries in East Java.

The results of this hypothesis testing are in line with the ones by Li et al. (2008), which suggests that there is a positive relationship between entrepreneurial orientation and company performance. To improve performance, entrepreneurial orientation is indispensable in an uncertain competitive environment. Likewise, for SMEs, entrepreneurial orientation is needed in the face of global competition, to improve its performance.

This study strengthens research from Idrus (1999) that entrepreneurial orientation (such as self-confidence, task-result oriented, risk-taker, leadership attitude, originality and futureoriented) greatly affects the success or performance. From the findings, it is known that the average value for entrepreneurial orientation is 4.07; this shows that the entrepreneurial orientation in the SMEs producing Indonesian special food in East Java is quite high. Likewise, the performance variable is known to have an average score of a high value of 4.00. The variable having the highest average score is the productivity of 4.11 . This means that SMEs have a good performance in terms of maintaining product quality, meeting production targets and time and being able to create new products.

\section{The effect of entrepreneurial orientation on business performance moderated by government policies}

GSCA results show a path coefficient value of -0.080 on the effect of government policies on performance and $p$-value of 0.849 (not significant) and a path coefficient value on the effect of $X 1 * X 3$ on performance of 0.126 and $p$-value of 0.772 (not significant), so the hypothesis is rejected. This shows that the government policy is not a moderating variable.

Thurik and Wennekers (2004) concluded that government policies in controlling the economy, by involving technology participation and consumer stability, would drive business performance. Some empirical studies show the role of government policies in improving the performance of small-scale enterprises. Empirical studies on entrepreneurial environments in different countries show that countries having fewer regulations and provisions, offering taxes and other incentives, promoting training and counseling services to those who start entrepreneurship will experience improvement and development of business (Dana, 2001). 
APJIE 13,2

The government policy variable is not moderation of entrepreneurial orientation and performance of SMEs producing Indonesian special food in East Java. This is presumably because there are other factors more influential in terms of performance of SMEs such as internal factors consisting of human resources, financial aspects, technical aspects of production or operations, and market and marketing aspects, and external factors consisting of socio-cultural and economic, and aspects of the role of related institutions.

Government policies can include improvement in the quality of human resources through training, strengthening capital by facilitating access to capital, and encouraging partnerships and providing protection for small businesses to increase business performance. The optimal role of government is manifested by becoming facilitators, regulators and catalysts. As a facilitator, the government has a role in facilitating SMEs to achieve the development goals. If SMEs have weaknesses in production, the government's job is to provide training. Development of SMEs is essentially a joint responsibility between the government and society. The government has sought to create a good climate among others, by maintaining the security of business and simplification of business licensing procedures, tax relief, and so forth. The development of mutually beneficial partnerships between SMEs and large entrepreneurs both within countries and abroad should be enhanced by the government to avoid monopoly in business and to expand market share and more efficient business management.

The government has enhanced training for SME actors related to entrepreneurship, management, administration, and other skills in developing their business. In addition, the government has provided an opportunity to practice the theory through the development of partnerships. The existing associations must be strengthened, to enhance their role, among others, in the development of business information networks indispensable for the development of business performance. To accelerate the process of partnership between SMEs with big business both from within the country and from abroad, special media are needed in an effort to promote the products produced. The government also promotes the local products of SME in other countries through the embassies in the country concerned.

This study shows that the government has not been able to play its role in maximizing the success of SMEs in Batu. One of the problems is the fact that SMEs find it difficult to get access to capital from the government-appointed banks. Most SMEs have no collateral to receive loan assistance from the bank. Therefore, the government must improve its involvement in assisting SMEs so entrepreneurs can improve business performance as well.

\section{The effect of business strategies on performance}

From the result of hypothesis testing, it is known that business strategies have a significant influence on the performance of SMEs producing Indonesian special food in East Java. The result of GSCA shows a path coefficient on the effect of competitive strategy on performance of -0.215 and $p$-value of 0.016 (significant) and the interaction effect of $Y 1 * X 2$ on performance of 0.217 and $p$-value of 0.036 (significant), so the hypothesis is accepted.

The results of this study strengthen the results of research conducted by Asmarani (2006) that business strategies positively affect the performance of SME tenun ikat in Troso, Jepara the better business strategy, the better performance of the company. The existence of a good business strategy can enable companies to achieve organizational goals established. This result is in accordance with research conducted by Rue and Ibrahim (1998) that SME shaving business strategies generally produce above-average performance than those with no business strategies. Muryati (2004) in her research examines the effect of external environmental factors and internal environmental factors either directly or indirectly to export performance. The study also tests the influence of the external environment and internal environment on 
competitive strategy intensity and tests the influence competitive strategy intensity toward export performance. Negative indirect relationships occur on internal factors to competitive strategy intensity and export performance because entrepreneurs do not improve their competence on internal function, as some functions have been taken by foreign buyers, such as pricing, promotion and distribution channels. To improve the intensity of competitive strategies, we must improve the quality and durability of the products, after-sales service, and the provision of payment terms and cost advantages.

Associated with the existing phenomenon, there are indicators used to measure business strategies showing good results, seen from the high average value of the indicator ranging from 3.61 to 4.03. The highest average indicator value is for the differentiation strategy (4.03), while the lowest value is for the focus strategy (3.61). Performance also has a high average score that ranges from 3.82 to 4.11 . The highest average score is for the productivity indicator (4.11), while the lowest average is for the market indicator (3.82). Thus, it can be said that SMEs producing Indonesian special food in East Java has a good ability in determining the right business strategy to improve business performance on SMEs.

\section{The effect of business strategies on performance mediating by environmental dynamics}

The result of GSCA shows a path coefficient of the effect of business strategies to performance is -0.215 and $p$-value of 0.016 (significant) and the interaction effect of $Y 1 * X 2$ on performance is 0.217 and $p$-value of 0.036 (significant), so the hypothesis is accepted. This shows that environmental dynamics act as a quasi-moderating variable. The results of this study extend the research conducted by Pono (2009), which shows that the dynamics of the environment and business strategy have a significant influence on the performance of manufacturing industry in East Java.

The results of this study indicate that the majority of SME producing Indonesian special food in East Java selects the differentiation strategy. This means that SMEs have the ability to set appropriate strategies for creating quality products, producing products that have more benefits than similar products on the market, formulating a variety of products, and providing exceptional service to their customers. The environmental dynamics often experienced by SME producing Indonesian special food in East Java is the intensity of competition (average score of 3.51). They experience many environmental dynamics in the form of product competition, promotion competition, price competition, distribution channel competition, and raw material competition. Thus, it can be said that SME producing Indonesian special food in East Java have the ability to define the right business strategy in accordance with the dynamics of the environment faced to increase their performance.

This study extends the study by Hashim, Wafa, and Sulaiman, the study examines the environment as a moderator of the relationship between business strategy and performance of 100 SMEs in Malaysia's manufacturing sector. Using ANOVA (Analysis of Variance), this study indicates that the three generic strategies by Porter are relevant not only to large companies but also to SMEs. In addition, the relationship between business strategy and $\mathrm{SME}$ performance is moderated by the environment. These findings require companies to implement business strategies based on the environment. The difference of the present study with the one by Hashim, Wafa and Sulaiman lies in the analysis technique, as the present study uses GSCA and the differentiation strategy is the focus of the study.

\section{Concluding remarks}

Further studies are suggested to continue examining the concept of environmental dynamics in different situations and to take samples on other types of businesses, as there are still many developing SMEs. It is also suggested to use government policies as a 
APJIE 13,2

dependent and independent variable, and a mediating variable, to know the effect on SME performance. Future researchers are advised to distinguish between SMEs and focus on the regional business group, and also to analyze the internal environment such as the capital structure, human resources, and technology that affect the performance of SMEs.

It is recommended that the government establish good cooperation with SMEs in Indonesia to assist in the development of SMEs. SMEs must stop their dependence on other parties so training on management and managerial skills are needed, so they can choose the right business strategy in accordance with the dynamics of the environment. Therefore, it is necessary to provide guidance for SMEs. The government must always provide continuous assistance and monitoring on the sustainability of SMEs so the business can continue to evolve.

Theoretical implications are the contribution of the development of science so that it can become a reference for reading and information in further research and in developing science, especially those related to strategy management and entrepreneurship. This study can prove and broaden the theory of the role of environmental dynamics as a moderating variable, where the determination of business strategies that are in line with the dynamics of the environment will be stronger in encouraging the performance of SMEs. While the practical implications of this research are for SMEs in Timor Leste, with agreed knowledge about entrepreneurship. SMEs are expected to be prepared about the development of entrepreneurs, both for entrepreneurship training, so that SMEs can be improved, in addition to knowing. For the Government, the results of this study can be used as input for the government specifically for the Ministry of Trade, industry and environment in developing and fostering SMEs in East Timor. For researchers, the results of this study will add the knowledge and key research insights in problems related to SMEs in the quality of entrepreneurship, environmental dynamics, government policies, business strategies and performance.

\section{References}

Albaladejo, M. and Romijn, H.A. (2000), "Determinants of innovation capability in small UK firms: an empirical analysis", Working Paper Series, Vol. 200013, Eindhoven Centre for Innovation Studies, Eindhoven.

Anand, G. and Ward, P.T. (2004), "Fit, flexibility and performance manufacturing: coping with dynamic environment", Production and Operations Management, Vol. 13 No. 4, pp. 369-385.

Antonio, M.T., Corredor, L. and Leret, M.L. (2003), "Study of the activity of several brain enzymes like markers of the neurotoxicity induced by perinatal exposure to lead and/or cadmium", Toxicology Letters, Vol. 143 No. 3, pp. 331-340.

Asmarani, D.E. (2006), Analisis Pengaruh Perencanaan Strategi Terhadap Kinerja Perusahaan Dalam Upaya Menciptakan Keunggulan Bersaing (Studi Empirik Pada Industri Kecil Menengah Tenun Ikat di Troso, Jepara), Tesis, Universitas Diponegoro, Semarang.

Brown, T. (1996), Resource Orientation, Entrepreneurial Orientation and Growth: How the Perception of Resource Availability Affects Small Firm Growth, Unpublished Doctoral Dissertation Rutgers University, Newark, NJ.

Covin, J.G. and Slevin, D.P. (1991), “A conceptual model of entrepreneurship as a firm behavior”, Entrepreneurship Theory and Practice, Vol. 16 No. 1, pp. 7-25.

Covin, J.G. and Slovin, D.P. (1989), "Strategic management of small firms in hostile and benign environment”, Strategic Management Journal, Vol. 10 No. 1, pp. 75-58.

Dana, L. (2001), "Industrial development efforts in Malaysia and Singapura", Journal of Business Management, Vol. 25 No. 3, pp. 74-86.

Dimitris, T. and Dimitris, S. (2004), "The effects of regional capital subidies on firm performance: an empirical study", Jurnal of Small Business an Entreprise Development, Vol. 11 No. 1, pp. 121-129. 
Fernandes, A.A.R. and Solimun, (2017), "The mediating effect of strategic orientation and innovations on the effect of environmental uncertainties on the performance of business in the Indonesian aviation industry", International Journal of Law and Management, Vol. 59 No. 6, pp. 1269-1278.

Glancey, K., Greig, M. and Pettigrew, M. (1998), "Entrepreneurial dynamics in small business service firms", International Journal of Entrepreneurial Behavior and Research, Vol. 4 No. 3, pp. 249-268.

Hashim, M.K., Wafa, S.A. and Sulaiman, (2001), "Testing environment as mediator between business strategy performance relationship: a study of Malaysian SME's", in 46th ICSB World Conference, Taipei.

Idrus, M.S. (1999), "Stratagi pengembangan kewirausahaan (entrepreneuershi) dan peranan perguruan tinggi dalam rangka membangun keunggulan bersaing (competitive advantage) Bangsa Indonesia pada Melinium ketiga”, Pidato Pengukuhan Jabatan Gurubesar Dalam Ilmu Manajemen, Universitas Brawijaya, Malang.

Lee, D.Y. and Tsang, E.W.K. (2001), "The effect of entrepreneurial personality, background and network activities on venture growth", Journal of Management Studies, Vol. 38 No. 4, pp. 583-602.

Li, Y., Zhou, Y., Tan, J. and Liu, Y. (2008), "Moderating effects of entrepreneurial orientation on market orientation-performance linkage: evidence from Chinese small firms", Journal of Small Business Management, Vol. 46 No. 1, pp. 113-133.

Lumpkin, G.T. and Dess, G.G. (1996), "Clarifying the entrepreneurial orientation construct and linking it to performance", Academy of Management Review, Vol. 21 No. 1, pp. 135-172.

McCarthy, B. (2003), "The impact of the entrepreneur personality on the strategy format and planning process in SME's", Journal of Management, Vol. 24 No. 1, pp. 154-172.

Mahmud Anomsari, A. (2011), "Analisis pengaruh orientasi kewirausahaan”, Kemampuan Manajemen, Dan Strategi Bisnis Dalam Peningkatan Kinerja Perusahaan (Studi Pada Usaha Kecil Menengah di Kawasan Usaha Barito Semarang), Disertasi, Universitas Dian Nuswantoro, Semarang.

Makhdoom, H.R., Li, C. and Asim, S. (2019), "Diffusion of innovation through individual and collective entrepreneurship: an empirical investigation in SMEs", Asia Pacific Journal of Innovation and Entrepreneurship, Vol.13 No. 1, pp. 89-107.

Marhaeni, A.A.I.N., Yuliarmi, N.N. and Setiawina, N.D. (2019), "Empowering small industry of wood carving handicraft in Bangli district", Asia Pacific Journal of Innovation and Entrepreneurship, Vol. 13 No. 1, pp. 121-136.

Menguec, B., Seigyoungh, A. and Eric, S. (2007), "Transformational leadership and market orientation: implications for the implementation of competitive strategies and business unit performance", Journal of Business Research, Vol. 60 No. 4, pp. 314-321. Elsevier.

Moeljadi, P. (1999), "Pengaruh beberapa facktor internal perusahaan dan asistensi pemerintah terhadap kinerja industri kecil di Jawa Timur", Jurnal Penelitian, Lembaga Penelitian Masyarakat Universitas Brawijaya.

(2004), Muryati, Intensitas Strategi Bersaing danKinerja Ekspor Pada Industri Kecil Produk Kerajinan Kayu di Propinsi Jawa Timur, Disertasi- tidak dipublikasikan, PPSUB, Malang.

Neshamba, F. (2003), "Growth and transformation among small business in Kenya”, pp. 1-19.

Nurhayati, (2004), Analisis Faktor-Faktor Yang Mempengaruhi Kinerja Dan Keunggulan Bersaing Usaha Kecil Yang Berorientasi Expor di Jawa Timur, Disertasi- tidak dipublikasikan, PPSUB, Malang.

Olson, D.E. (2000), "The role of entrepreneurial personality characteristic on entry decisions in a simulated market", USASBE/SBIDA, pp. 1-13.

Pelham, A.M. (1999), "Influence of environment, strategy, and market orientation on performance in small manufacturing firms", Journal of Business Research, Vol. 45 No. 1, pp. 33-46.

Pono, M. (2009), "Pengaruh dinamika lingkungan, strategi bersaing dan strategi operasi terhadap kinerja perusahaan (studi pada industri manufaktur di sulawesi selatan)", Jurnal Aplikasi Manajemen, Vol. 7 No. 4, pp. 994-1005.
Entrepreneurial orientation in East Java 
APJIE 13,2

Porter, M. (1993), Competitive Strategy, Collier Macmillan, New York, NY.

Rasiah, R. (2002), "Government business coordination and small entreprise performance in the machine tools sector in Malaysia”, Small Business Economics, Vol. 18 Nos 1/3, pp. 177-195.

Riyanti, B.P.D. (2003), Kewirausahaan Dari Sudut Pandang Psikologi Kepribadian, Grasindo, Jakarta.

Rue, L.W. and Ibrahim, N.A. (1998), "The ralationship between planning sophistication and performance in small businesses", Journal of Small Business Management, Vol. 36 No. 4, pp. 24-32.

Rust, N.C., Schultz, S.R. and Movshon, J.A. (2002), "A reciprocal relationship between reliability and responsiveness in developing visual cortical neurons", The Journal of Neuroscience, Vol. 22 No. 24, pp. 10519-10523.

Steward, W.H., Jr, Carland, J.C., Carland, J.W., Watson, W.E. and Sweo, R. (2003), "Entrepreneurial dispositions and goal orientations: a compative exploration of United States and Russian entrepreneurs", Journal of Small Business Management, Vol. 41 No. 1, pp. 27-46.

Stuart, T. (2009), Waste - Uncovering the Global Food Scandal, Penguin Books, London, UK.

Suci, R.P. (2009), Peningkatan Kinerja Melahi Orientasi Kewirausahaan, Kemampuan Manajemen, Dan Strategi Bisnis (Studi Pada Industri Kecil Menengah Bordir di Jawa Timur), Disertasi, Pascasarjana, Univertas Brawijaya. Malang.

Suryana, (2006), Kewirausahaan, Pedoman Praktis, Kiat Dan Proses Menuju Sukses, Edisi Revisi. SALEMBA EMPAT, Jakarta.

Thurik, R. and Wennekers, S. (2004), "Entrepreneurship, small business and economi growth”, Journal of Small Business and Enterprise Development, Vol. 11 No. 1, pp. 140-149.

Tseng, C. and Tseng, C.C. (2019), "Corporate entrepreneurship as a strategic approach for internal innovation performance", Asia Pacific Journal of Innovation and Entrepreneurship, Vol. 13 No. 1, pp. 108-120.

Vitale, R., Giglierano, J. and Miles, M. (2003), "Entrepreneurial orientation, market orientation, and performance in estableshed and startup firms", International Journal of Business and Management Invention, Vol. 3 No. 12, pp. 08-17.

\section{Further reading}

Dess, G.G. and Davis, P.S. (1984), "Porter's (1980) generic strategies as determinants of strategic group membership and organizational performance", Academy of Management Journal, Vol. 27 No. 3, pp. $467-488$.

Lindh, C. and Nordman, E.R. (2017), "Information technology and performance in industrial business relationships: the mediating effect of business development", Journal of Business and Industrial Marketing, Vol. 32 No. 7, pp. 998-1008.

\section{Corresponding author}

Benny Hutahayan can be contacted at: benny.hut.ub@gmail.com

For instructions on how to order reprints of this article, please visit our website: 